\title{
Outward investment from the Netherlands: introduction and overview
}

Citation for published version (APA):

van Hoesel, C. P. M., \& Narula, R. (1998). Outward investment from the Netherlands: introduction and overview. MERIT, Maastricht Economic Research Institute on Innovation and Technology. MERIT Research Memoranda No. 008 https://doi.org/10.26481/umamer.1998008

Document status and date:

Published: 01/01/1998

DOI:

10.26481/umamer.1998008

Document Version:

Publisher's PDF, also known as Version of record

\section{Please check the document version of this publication:}

- A submitted manuscript is the version of the article upon submission and before peer-review. There can be important differences between the submitted version and the official published version of record.

People interested in the research are advised to contact the author for the final version of the publication, or visit the DOI to the publisher's website.

- The final author version and the galley proof are versions of the publication after peer review.

- The final published version features the final layout of the paper including the volume, issue and page numbers.

Link to publication

\footnotetext{
General rights rights.

- You may freely distribute the URL identifying the publication in the public portal. please follow below link for the End User Agreement:

www.umlib.nl/taverne-license

Take down policy

If you believe that this document breaches copyright please contact us at:

repository@maastrichtuniversity.nl

providing details and we will investigate your claim.
}

Copyright and moral rights for the publications made accessible in the public portal are retained by the authors and/or other copyright owners and it is a condition of accessing publications that users recognise and abide by the legal requirements associated with these

- Users may download and print one copy of any publication from the public portal for the purpose of private study or research.

- You may not further distribute the material or use it for any profit-making activity or commercial gain

If the publication is distributed under the terms of Article $25 \mathrm{fa}$ of the Dutch Copyright Act, indicated by the "Taverne" license above, 


\section{OUTWARD INVESTMENT FROM THE NETHERLANDS: INTRODUCTION AND OVERVIEW ${ }^{1}$}

Roger van Hoesel and Rajneesh Narula

\section{Forthcoming in, [R. van Hoesel and R.Narula (eds)] 'Multinationals from the}

Netherlands', London: Routledge, 1998

\section{INTRODUCTION}

Since the days of the Dutch East India company the economy of the Netherlands has been heavily dependent on overseas activities of its firms. Despite the end of the colonial era, the Netherlands has continued to be a significant player in the world economy, unlike similar historically dominant trading nations such as Portugal and Spain. Business overseas is not just restricted to trading activities but is also carried out through foreign direct investment (FDI) by its multinational enterprises (MNEs) and, more recently, through strategic alliances and networks. Indeed, the Netherlands is home to some of the world's largest multinationals. As will be illustrated in this chapter, even on an absolute basis, the Netherlands is the sixth largest outward investor in the world. Despite the long history of international economic activity and the dominant role of Dutch MNEs in the world economy, relatively little

1. We would like to thank Annelies Hogenbirk and Astrid Kusters of the University of Maastricht for their research assistance in preparing this chapter. We would also like to thank Prof. Dr. van Nieuwkerk of the Nederlandsche Bank for providing us with some of the data used here. 
academic research has been undertaken towards systematically evaluating these phenomena ${ }^{2}$. This volume attempts to fill this gap.

In this introductory chapter, we will illustrate the rather unique position the Netherlands has as a home country of outward investment and touch upon some of the insights into this phenomenon as presented in the other chapters of the volume. To this end, first some characteristics of the Dutch economy will be compared with those of other major outward investors. Subsequently, the overall position of the Netherlands as an outward investor in comparison with other countries will be discussed. Next, the regional and sectoral shifts in FDI that have taken place over time will be examined. In the final section, a profile of the most important Dutch MNEs will be drawn.

\section{STRUCTURE OF THE DUTCH ECONOMY: SOME CHARACTERISTICS}

Although many characteristics of the Netherlands will be analysed in more detail in other chapters of this book, in this section we will briefly address a number of features of the Dutch economy which have shaped the outward investment pattern of the country. In Table 1.1, some basic indicators of the Netherlands and a number of other major outward investors are depicted. From the Table, some interesting observations can be made. First of all, the figures illustrate that -in comparison with most other home countries of MNEs- the Netherlands is a small country, both in terms of its population and the size of its economy. In fact, only Switzerland is smaller. As can be derived from Table 1.1, in terms of the welfare level the Netherlands is not exceptional; only Switzerland and the US show considerably higher per capita GDPs (measured in terms of purchasing power parity).

\section{****TABLE 1.1 ABOUT HERE****}

2. The most notable exception is a study carried out by van Nieuwkerk and Sparling (1985) more than a decade ago. 
Regarding the sectoral composition of the economies, we note that in the case of the Netherlands the primary sector (especially agriculture and natural gas) contributes somewhat more to the country's GDP than in the other countries. Furthermore, the services sector generates a relatively large number of jobs (some 73\%) as compared with most of the other countries listed.

Most striking, however, is the extraordinary importance of international trade activities for the Dutch economy. Although it is quite common for smaller economies to depend more heavily on overseas business activities than their larger counterparts, the ratios of exports as well as imports to GDP are extremely high - also in comparison with Switzerland. Part of the explanation is the special function the Netherlands has as a major distribution centre for continental Europe. Although many Dutch companies do indeed have their most important markets abroad, a substantial share of the trade figures do not reflect the production of final goods in the Netherlands but 'merely' reflects the re-export and transit of goods produced elsewhere (OECD, 1996). However, this observation does not diminish the strong outward orientation of the country.

Table 1.2 renders a view on the relative economic performance of the Dutch economy over time. In the Table, the Netherlands is compared with Northwest European countries (which, broadly speaking, share similar economic characteristics), the European Union (EU), and the OECD as a whole. In terms of real GDP per capita the Table shows that for the whole period (1960-1994), the growth for the Netherlands was somewhat lower than that in other Northwest European countries and considerably lower than in the EU and the OECD. Given the lower welfare base from which the more recent (South European) EU and OECD member states commenced, the latter is no surprise. Especially during the period 1960-1987 the performance of the Dutch economy was relatively poor. In more recent years, the economy performed much better and even surpassed the performance of countries mentioned in the other categories in the Table. In 1994, the per capita GDP level in the Netherlands was only 4 percentage points lower than in the other Northwest European economies implying a substantial improvement from the previous period. Given the relatively high growth figures that are being realised at present, the position of the Netherlands is expected to equal or even surpass that of quite a number of other economies in the region. The welfare level vis-à-vis the EU and the OECD as a whole was considerably higher. 
****TABLE 1.2 ABOUT HERE****

In terms of the growth of labour productivity, the picture looks different. Table 1.2 reveals that until 1987, the growth of labour productivity in the Netherlands was quite high; since then, it has considerably dropped behind that of other Northwest European countries, the EU as well as the OECD. Notwithstanding this relatively low growth since the late 1980s, labour productivity is still at a very high level and clearly exceeds productivity in other economies.

Van Essen and Verspagen discuss the technology characteristics of the Dutch economy in Chapter 3. The authors show that total R\&D efforts in the Netherlands have been relatively modest as compared to other leading countries but are rather similar to those of other small countries such as Sweden, Finland, Switzerland, and Denmark. It turns out that, whereas the public R\&D efforts are well developed, business R\&D in the Netherlands is carried out at a relatively small scale and low intensity. According to van Essen and Verspagen, this - inter alia - can be attributed to the very specific structure of Dutch business, with much of Dutch R\&D activities being concentrated in five large MNEs. As Cantwell and Janne show in Chapter 4, Dutch MNEs carry out a relatively large share of their R\&D activities abroad. Given the limited size of the Dutch economy, only a limited range of technological sectors are covered in enough detail. The transplantation of $R \& D$ activities to other countries is thus not fully compensated by the activities of foreign companies in the Netherlands. Another explanation for the limited business R\&D activities in the Netherlands proposed by van Essen and Verspagen is the relatively large role of small business in the Dutch economy. The authors also argue that the sectoral structure (with a large share of the services sector) of the Netherlands also partly explain the modest R\&D performance.

Cantwell and Janne in Chapter 4 examine the internationalisation of R\&D activities of Dutch MNEs in comparison with their leading European competitors. Although the gap has closed somewhat since the 1980s, they show that the largest Dutch industrial MNEs are still among the most internationalised in terms of their research activities. The authors argue that the large MNEs have successfully combined the resources available to several geographically dispersed units. Interestingly, firms tend not only to build on fields of strengths they had already established at home, but also broaden their technological capabilities over time by 
taking advantage of local sources of expertise and innovation in each site. Cantwell and Janne illustrate that mergers \& acquisitions have played an important role in this respect.

\section{****TABLE 1.3 ABOUT HERE****}

In view of its importance to the Dutch economy, a final remark in this concise introduction to the Dutch economy concerns the destination and composition of exports. In Table 1.3 the geographical destination of Dutch exports is listed, whereas the share of the various product groups over time is shown in Table 1.4. Table 1.3 clearly illustrates that Europe has remained by far the most important destination of Dutch exports. Although the share of the EU and EFTA has gone down somewhat, in 1994 still a great majority of Dutch products remained on the European continent. The Table also illustrates that the importance of the USA as an export destination has remained rather low during the last two decades and is even more modest than Dutch exports to Asia. Finally, we observe than in recent years the geographical destination of Dutch exports has become somewhat more diversified although an important part of the new target markets is located in Eastern Europe.

\section{****TABLE 1.4 ABOUT HERE****}

What are these exports composed of? Table 1.4 shows that a large majority of Dutch exports consists of manufactures. The most important product groups are metal manufactures (including electronics), chemicals, and food, beverages and tobacco. Interesting to note in this respect in that, although some fluctuations did take place, grosso modo the relative importance of the goods exported from the Netherlands has not changed much during the last two decades. This implies that also the relative knowledge extensive industries -such as food, beverages and tobacco and textiles- have continued to play an important role for the Dutch economy ${ }^{3}$.

3. We would like to emphasise, however, that one has to be cautious in labelling industries as 'knowledge (or R\&D) intensive or extensive'. Not only can important variations exist within these (broad) sectors, but also important technological advances have been observed in 


\section{THE NETHERLANDS AS AN OUTWARD INVESTOR: A COMPARISON}

In Chapter 2, de Goey describes how, since the 17th century, Dutch companies built up a world-wide presence. Important pioneers were the Dutch East India company (VOC) and the Dutch West Indies company (WIC) which in the 17th and 18th century created trading settlements in a large number of countries. These trading activities generated enormous wealth, making the Netherlands one of the most prosperous countries in the world. When the opportunities to invest at home became saturated in the second half of the 18th century, the capital flowing abroad really gained momentum. As de Goey points out, this capital was utilised for a wide variety of purposes, ranging from the provision of loans to the US government to support their independence war, to the exploitation of plantations in Surinam. After a serious recession in the first half of the 19th century, the Netherlands re-emerged as one of the leading capital exporters in the world, and has remained a net capital exporter ever since.

Although cross-country capital exports have been registered for centuries, foreign direct (as opposed to portfolio) investment only assumed substantial proportions in the twentieth century. From the 1960s onwards, the size of global FDI grew substantially, but especially in the decades that followed the overseas presence through direct investment went up drastically. Whereas from the 1970s improved transportation facilities, innovations in communication systems, and growing protectionism motivated companies to invest abroad (Belderbos, 1989), since the 1980s globalisation tendencies and the emergence of new home bases of MNEs accelerated the overseas presence of companies at an unprecedented pace. In this section, the outward investment position of the Netherlands will be compared with that of other home countries. In Table 1.5, a number of indicators are listed from which some interesting observations can be drawn.

****TABLE 1.5 ABOUT HERE****

traditionally non-R\&D intensive sectors. 
First of all, the Table underlines the enormous growth of overseas presence of companies through FDI in the world during the last two decades. Global outstanding investment stock went up from US\$ 280 billion in 1975 to US\$ 2,238 billion in 1944 - an almost tenfold increase. Notwithstanding the emergence of important new outward investors, the Netherlands has to a large extent been able to maintain its relative position. Its share in global FDI stock went down by only 1 percentage point from $7.1 \%$ in 1975 to $6.1 \%$ two decades later. The peak of Dutch presence was recorded in 1980, when $8.2 \%$ of outstanding FDI stock in the world originated in the Netherlands - making the country the fourth largest investor in the world. At present, the Netherlands still occupies the sixth largest position. The drop on the outward investor ladder can be largely ascribed to the emergence of Japan as a major investor and -to a lesser extent- the increased overseas investment activities by Germany, France and Italy. The substantial decrease of the share of the US in global FDI stock has been particularly remarkable (from $44.3 \%$ in 1975 to $25.7 \%$ in 1994). This illustrates an erosion of the technological, managerial, and commercial superiority the US possessed in many industries vis-à-vis other parts of the world (Dunning 1993). In recent years, the relative importance of Switzerland has gone down considerably, while that of Japan 
has grown ${ }^{4}$.

If we take the size of the countries into account, the position of the Netherlands is even more remarkable. Just behind Switzerland, the Netherlands on a per capita basis has invested most capital abroad (i.e. US\$ 9,494 at the end of 1994), which is much more than the other countries listed in the Table. The outward direct investment stock (FDI stock/GDP ratio for the Netherlands is even the highest by far, suggesting that no other country undertakes such a large part of its economic activities outside its own borders. A last indicator mentioned in Table 1.5 is the FDI stock to export (FDI stock/EXP) ratio. Although FDI and export certainly cannot be considered (perfect) substitutes (cf. Narula, 1996), it does render an indication of the relative importance of these modes of international business. Interestingly, the position of the Netherlands in this respect is much less extraordinary. In 1994, for instance, the UK, Switzerland and the US all showed higher FDI stock/EXP ratios. Although,

4. An important weakness of the stock figures usually published (which are also used here) is that they are valued at their historical costs instead of present values. As a result, 'older' investments are seriously undervalued if compared with more recent projects. This also implies that the total stock value of countries that registered early FDI in reality reflect a more extensive overseas presence than that of more recent outward investors. However, data restrictions prevent re-evaluation of FDI to adjust for this. See Cantwell and Bellak (1994) for further discussion on this issue, and an attempt at re-evaluation. 
this can partly be explained by the prominent position exporting takes in the Dutch economy, as we have we noted already, part of these trading activities reflect the re-export and transit of goods that are not produced in the Netherlands. If we take this phenomenon into account, the FDI stock/EXP ratio for the Netherlands probably would go up considerably.

\section{GEOGRAPHICAL AND SECTORAL TRENDS}

In this section, the trends in overseas investment originating in the Netherlands are examined more carefully. First, the geographical destination of Dutch FDI will be examined. Subsequently, the sectors in which companies invested are analysed. In Tables 1.6 and 1.7 the geographical and sectoral breakdown of FDI stock respectively are listed for a number of years ${ }^{5}$.

\section{Geographical trends}

Unfortunately, until very recently only a small number of host countries of Dutch MNEs were specified in the statistics published by the Dutch Central Bank ('De Nederlandsche Bank'). Nonetheless, a picture can be drawn of the importance of the various regions where Dutch companies are active through FDI as well as the trends which have occurred during the last two decades. First, Table 1.6 illustrates that a great majority of Dutch FDI has gone to the European Union and the United States. In fact, the relative importance of the EU and US taken together has even increased from $64.6 \%$ in 1973 to $73.9 \%$ in 1995. Between 1973 and 1995 the stock of Dutch FDI in the European Union went up about six times from some fl 22 billion to more than fl 139 billion. The share of the EU as a destination for Dutch MNE activity has declined somewhat in this period, but still accounts for almost half of all outstanding investments (i.e. $49.2 \%$ at the end of 1995). The present share is substantially higher than ten years ago when 'only' $32.8 \%$ had gone to other EU member states. This temporary dip in popularity of the home region coincided with an increased

5. 1973 is the first year for which these data were published. 
interest in investing in the US. The EU 1992 Treaty again boosted investment in the EU resulting in a higher share in total Dutch FDI. New market potentials and the need to restructure existing production operations in Europe resulted in a strong upswing of FDI.

The Table further shows substantial fluctuations in the relative importance of the EU members as host countries for MNEs from the Netherlands. The share of Belgium and Luxembourg, for instance, went up from 7.1\% of total global Dutch FDI stock in 1973 to $13.3 \%$ in 1995 whereas the relative importance of Germany went down from $18.8 \%$ to $7.8 \%$ in the same period. Another important host country is the United Kingdom, whose share varied considerably during the last two decades. An important determinant in the case of Dutch FDI in the UK concerns the activities of several Anglo Dutch conglomerates such as Shell, Unilever, and Reed-Elsevier. Next to the EU countries, Switzerland has emerged as an important target country in Europe having absorbed 6.7\% of outstanding Dutch FDI at the end of 1995. Although Central and Eastern Europe in recent years have attracted the attention of Dutch MNEs, their relative importance as a host region is still relatively modest accounting for a scant $1.0 \%$ of total outstanding FDI.

\section{****TABLE 1.6 ABOUT HERE****}

Outside Europe, the US has always been by far the most important target region ${ }^{6}$. In the period concerned, FDI stock in the US went up from fl 6.2 billion to fl 69.8 billion implying a more than tenfold increase. Narula and Hogenbirk explored the trends in Dutch investment in the US at length in Chapter 8. The authors show, inter alia, that at one point in time in the 1980s, Dutch MNEs accounted for no less than one-quarter of all FDI stock in the US. It appears that such factors as the large homogenous market, advanced technological environment, political stability, and societal and economic freedom have been important pull factors that stimulated Dutch companies to invest in the US (van Nieuwkerk and Sparling, 1985). The increasing saturation of the traditional European markets combined with the relatively imperfect functioning of these markets in the 1980s led to a pull away from Europe

6. In Chapter 2, de Goey shows that Dutch investors have historically been very active in the US. 
towards the US. As Narula and Hogenbirk point out, the competitiveness of Dutch firms in that period was superior to that of their European rivals. Since then, however, the share in US manufacturing has gone down, suggesting a decline in the competitive strengths vis-à-vis other countries. In addition, the further unification of the EU in 1992 and the emergence of new major investors such as Japan, has led to an increased emphasis on investments in European countries. Moreover, the changing structure of the Dutch economy in favour of the services sector and at the expense of the manufacturing sector has caused as drop in manufacturing FDI. Nevertheless, at the end of 1995, the US had still attracted about onequarter of outstanding Dutch FDI.

In Chapter 9, Belderbos discusses the activities of Dutch MNEs in Japan. Analysing aggregate as well as micro level data, the author argues that the operations of Dutch companies in Japan reflect regulatory and economic conditions that have affected inward FDI in Japan at large. Until very recently, locational disadvantages and a range of entry barriers kept inward investment growing at a very low rate. What remains striking, however, is the near absence of many of the most internationalised Dutch MNEs in Japan, which have otherwise been very active in Europe and the US. It is also worth noting that Dutch subsidiaries in Japan export more from Japan than they import. Philips, for instance, uses its Japanese manufacturing base to establish and improve linkages with the strong local supply base and locally available R\&D infrastructure.

With regard to the developing (non-OECD) countries, Table 1.6 shows that the picture has changed considerably over time. Important variations can be observed between the various developing regions. Although its share has dropped (from 11.9\% in 1973 to $6.5 \%$ in 1995), Latin America and the Caribbean is the most important host region for Dutch MNEs outside the OECD area. However, at the same time we note that almost half of these investments have flown to the Netherlands Antilles where shell companies are primarily set up to make use of favourable tax regulations. If FDI in the Netherlands Antilles are excluded, developing Asia is the most important non-OECD host region. The share of Dutch FDI stock that has gone to Asian countries has gone up from 3.9\% in 1973 to $4.9 \%$ in 1995.1994 figures suggest that within this region, Hong Kong is by far the most important destination of 
Dutch MNEs accounting for 3.6\% of total FDI stock ${ }^{7}$. The interest in Hong Kong stems not only from attractive locational advantages of the city state itself. Quite a number of companies also use Hong Kong as a base to conduct business in the People's Republic of China (see Harold and Lall 1994). Other relatively important destinations in Asia are Singapore (1.0\% in 1994) and Taiwan (0.6\% in 1994). This brings us to our next observation, namely that outside the OECD area, Dutch MNEs have primarily focussed on higher income developing countries. As was also observed by van Nieuwkerk and Sparling (1985), this preference for the more advanced host economies appears to have been in place for a longer time. In view of this preference, it is no surprise that the share of Dutch FDI going to Africa is only very small and that the actual amount invested in the continent since 1985 has even gone down ${ }^{8}$.

\section{Sectoral trends}

In Table 1.7, a sectoral breakdown of Dutch FDI stock for a number of years is given. Some remarkable trends emerge from the Table. The most striking change during the period 1973-1995 is the tremendously increased importance of FDI in the tertiary sector. Its share in total Dutch FDI stock went up from $13.2 \%$ in 1973 to $49.0 \%$ in 1995 . This coincided with a decreasing share for the industrial sector which went down from $86.5 \%$ to $50.9 \%$. Yet, the total amount invested in industrial activities grew in this period from fl 38.2 billion to fl 143.9 billion.

****TABLE 1.7 ABOUT HERE****

7. For 1995, such detailed figures were not yet available.

8. In the 1980s oil exploitation had resulted in Dutch investments of some importance. 
Within the industrial sector, chemicals, coal, and petroleum are the most important targets. Their relative importance has dropped considerably over the years, however. Whereas (taking these industries together) at the end of 1973 no less than $47.4 \%$ of total Dutch overseas investment originated in this sector, this share had gone down $26.5 \%$ at the end of 1994. Another important source of outward FDI is food, beverages and tobacco from which 9.6\% of outstanding FDI at the end of 1995 had originated. Furthermore, as is shown in Table 1.7, metal products (including electronics) has contributed considerably to Dutch overseas production activities. However, the shares of these sectors have also gone down substantially during the last two decades. As will be illustrated in the next section, the sectors just mentioned are precisely those in which the 5 largest industrial Dutch MNEs (Shell, AkzoNobel, DSM: chemicals and oil; Unilever: food and beverages; and Philips: electronics) are active ${ }^{9}$.

As we noted earlier, Dutch FDI in the services sector has witnessed astonishing growth. Although no fundamental differences exist between services and production-related MNEs regarding the way in which they decide to establish local subsidiaries abroad, Stibora and de Vaal in Chapter 5 point out that a major distinction is that primary and secondary goods can in principle always be sold through exports. In the case of services activities, there is often no choice: their output has to be sold abroad through a physical presence. As was pointed out earlier the service sector plays a very important role in the Dutch economy - even when compared to other economically advanced countries. Their dominance is not confined to the domestic economy, however. Also internationally, the services sector has become very substantial. Stibora and de Vaal illustrate that the Netherlands has acquired a relative comparative advantage in almost all subsectors of the services sector. In the non-services sector, on the other hand, such strong position is observed in far fewer subsectors. In view of the fact that this pattern deviates considerably from most other OECD countries, the authors

9. According to van Nieuwkerk and Sparling (1985), nearly three-quarters of the Dutch investment position abroad is accounted for by the ten largest MNEs. 
conclude that the Netherlands over time has increasingly specialised in services, especially in banking and insurance. FDI stock in the services sector went up from fl 5.8 billion at the end of 1973 to fl 138.5 billion in 1995, implying an increase of more than 20 times! Table 1.7 illustrates that finance, insurance and business services (36.2\% of total Dutch FDI stock) and wholesale and retail trade (10.5\%) are by far the most important sources.

\section{GENERAL TRENDS IN DUTCH MNE ACTIVITY}

It is not surprising, given the significance of trade and outward FDI activity to the Dutch economy, that the Netherlands is home to a large number of MNEs. Table 1.8 gives the latest available data on outward FDI stock by country and sector for 1995. This illustrates well the extent of the activities of Dutch firms overseas, in terms of both scale and scope. In this section, we examine the firm-level changes and developments that underlie the macro data. In addition to their sheer size in terms of dominance of outward FDI stocks, Dutch MNEs are also generally considered as competitive on a global scale, not just in terms of price and quality, but are also amongst the most technology-intensive in their respective sectors. These facts are axiomatic, and are considered a general feature of small open economies (see for example, Freeman and Lundvall [eds] 1988, Dunning and Narula 1996 and the discussion by van Tulder in chapter 10 of this book). This body of literature has illustrated that small open economies tend to be more internationalised, with a relatively large share of the value-added activity being conducted with the explicit purpose of serving overseas markets. Furthermore, firms from these countries tend to be competitive in a few niche sectors, as small countries tend to have limited resources and prefer to engage in activities in a few targeted sectors, rather than spreading these resources thinly across several industries.

\section{****TABLE 1.8 ABOUT HERE****}

Nonetheless, Dutch MNEs (along with those from Switzerland), while displaying these general traits, are also something of an outlier, demonstrating a pre-eminence amongst small open economies. The Netherlands acts as a 'large' small country, not only in terms of the scale, but also in terms of the industrial scope of the activities of its firms. Dutch firms 
form two distinct types. First, there are those in a large number of sectors behaving in a 'small country' way, where production is atomistic: a large number of small and medium size firms, primarily focussed on supplying large firms locally or exporting to foreign owned establishments overseas, and that tend to be in a few very focussed industrial sectors. The second group are the large conglomerates with interests in several -often disparate - sectors, the names of whom are familiar to everyone, and tend to be market leaders in the industries in which they operate, not just in the Netherlands, but on a worldwide basis. The first group is unspectacular - every country, small or large, has such firms. The second group, on the other hand, is unusual by any standards. Table 1.9 lists a number of Fortune 500 firms in 1995, by parentage for some of the smaller industrialised economies worldwide. With the exception of Swiss MNEs, Dutch firms are significantly larger, and are engaged in a wider range of industries than firms from other countries. The 10 largest companies accounted for an unwieldy $78 \%$ of total market capitalisation in the Netherlands at the end of 1993. Of these 10, three firms: Royal Dutch/Shell, Unilever and the ING group, accounted for over $50 \%{ }^{10}$.

*****Table 1.9 about here $* * * *$

As several of the chapters in this book illustrate, the activities of Dutch firms has undergone considerable change since the early 1980s. Although these changes have affected firms from different sectors to varying extents, there are nonetheless some interesting general trends that can be said to be near-universal. First, there has been a rationalisation of activities in order to cope with the establishment of the single market within the European Union. This is both a defensive and an offensive strategy, because similar rationalisation has been occurring across most European countries, as firms prepare for more cross-border competition where activities hitherto were more or less confined to national boundaries. Firms from countries with small home country markets such as the Netherlands have tended not to have the economies of scale to compete with firms from the larger European countries, particularly so in the financial service sectors, such as banking and insurance. Dutch MNEs, in a pattern 10. Euromoney, pp. 348-352, September 1994. 
that seems to have duplicated itself across most European firms, have engaged in a rationalisation of their European operations partly in an attempt to conform to (and to take advantage of) the gradual implementation of the directives leading to the single market in the 1980s, particularly in manufacturing. Similar adjustment did not occur in the banking and services sector till the 1990s, however, as the agreement on a single currency was not begun in earnest until early in this decade. Second, there has been a liberalisation of markets on a global scale as sectors such as insurance, real estate, retailing, and utilities have seen a reduction in restrictions on FDI, particularly as a result of the completion of the Uruguay round. Third, these two factors have led to a liberalisation of the domestic market in the Netherlands, that has seen the growing presence of foreign firms, which have been chipping away at a previously relatively captive market. Fourth, the slowing down of economic growth in most of the industrialised countries has meant that firms have increasingly had to seek new markets outside their traditional markets. In the case of Dutch MNEs, this has meant reducing the emphasis on Western Europe, and seeking or expanding their presence, particularly in Asia, but also in Latin America and Eastern Europe. Fifth, in the manufacturing sector, the reduction in trade barriers and the continuing high cost of production in Europe, has led to a rationalisation and relocation of production to low-wage regions, which, not coincidentally are also fast growing markets for some of these products. The next section examines some of the changes that have occurred amongst specific MNEs in several of the more important sectors.

\section{A PROFILE OF DUTCH MNES}

\section{Manufacturing sector}

The international activities of Dutch manufacturing MNEs are very much dominated by four large firms - Unilever, Royal Dutch Shell, Philips, and Akzo-Nobel. As Table 1.10 shows, these four firms dominate most economic statistics, together accounting for almost $50 \%$ of the sales of the 100 largest firms in the Netherlands. Indeed, according to UNCTAD (1996), Unilever, Shell, and Philips are the ninth, tenth, and $27^{\text {th }}$ most internationalised MNEs in the world, and in absolute terms, Unilever and Philips have the two largest number of overseas employees of any firm in the world, together employing about half a million people 
overseas.

****Table 1.10 about here $* * * *$

The cases of Unilever and Shell, both Anglo-Dutch conglomerates, provide a very rosy picture of the state of MNEs from the Netherlands. Shell has consistently been the most profitable, or one of the most profitable companies in the world for several years, which is attributed to its ability to spread its risk and ride through slowdowns and recessions in different parts of the world by being geographically diversified ${ }^{11}$. Shell manages operations in 120 countries. It has also been trimming its operations - in particular this has meant a reduction in its US operations, where it has been gradually reducing its involvement (see Chapter 8), while making relatively risky (but potentially hugely profitable) investments in the former Soviet republics. However, Shell has also trimmed itself in terms of its industrial diversity, focussing on a few core businesses, having sold or reduced its holdings in coal and chemicals, with an eye on exiting other non-petroleum mining operations ${ }^{12}$. Unilever, which along with arch-rivals Nestlé and Procter and Gamble, is increasingly locked in a competition to dominate the global food and personal-care products industries. All three of these large MNEs have been engaging in numerous take-overs, acquisitions, and disposals to achieve rationalised, global positions, particularly given the relatively low margins in this industry. As an example, in the first half of 1996, Unilever made 24 acquisitions and 15 disposals at a net cost of almost fl 3 billion ${ }^{13}$. Chapter 7 discusses trends in Dutch MNE mergers and acquisitions in some detail.

11. Fortune, pp. 71-75, August 51996.

12. Forbes, pp. 92-94, November 91992

13. Financial Times, p.10, August 101996 
The continuing struggle of Philips to adapt to the realities of increased global competition and the volatility of the consumer electronics market, has continued to dominate the forecasts for the Dutch manufacturing sector. The economic well-being of Philips tends to dominate the landscape of Dutch outward FDI in manufacturing, and indeed the Dutch manufacturing sector, directly employing over 260,000 people worldwide in 1995 , and 44,000 in the Netherlands alone. In addition to refocusing their activities to a few core sectors, they have cut costs to achieve the price competitiveness that US and Japanese firms have achieved through similar attempts at re-focussing conducted through the early 1990s. The sale of its controlling stake in Germany's Grundig, and large lay-offs (particularly in the Netherlands), as well as the decision to re-align their R\&D towards more short-term and applied research are just three ways in which Philips has tried to do so. It has also re-located production to low-wage countries such as China where Philips had nine joint ventures as of late 1996. At the same time, it has sought to enter new markets, by developing expertise in flat-screen technology, a sector that has hitherto been dominated by Japanese firms. In particular, Philips has established the only flat-screen manufacturing facility in Europe that is not Japanese controlled, and in fact have been acquiring flat-panel manufacturing capacity in Japan (Chapter 9). In addition, the merger of the telephone manufacturing operations of Philips and Lucent technologies is expected to make it more competitive in the mobile communications sector, since the joint venture will have revenues of US\$2.5 billion and access to the technological expertise of both companies ${ }^{14}$. These restructuring woes do not extend to Polygram, which, although a subsidiary of Philips, has remained largely independent in its operations, and continues to be one of the largest and most successful entertainment groups, having gradually expanded their presence from music to television and films.

The case of Akzo-Nobel is another very good example of restructuring to face the challenges of the new economic realities. Akzo (itself a product of the merger between Algemene Kunstzijde Unie [AKU] and Koninklijke Zout Organon [KZO] in 1969), successfully acquired Nobel industries of Sweden in 1994, to become the world's largest producer of paints and industrial coatings with revenues of fl 22 billion (Table 1.10), and 70,000 employees in 1996. At the same time it is actively restructuring itself by dismantling its five division structure and replacing it with 34 business units clustered in four groups

14. Financial Times, p.29, June 181997 
based on their technical and commercial synergies ${ }^{15}$. It has also cut costs by deliberately reducing its $R \& D$ expenditure to $20 \%$ less than its needs, forcing managers to seek external sources for technology ${ }^{16}$. Furthermore, Akzo-Nobel has sought to focus its industrial distribution, by undertaking either to sell its non-core holdings, or to partner with other firms.

The printing and publishing sector has also gone through a revitalisation, in this case marked by a series of mergers. Elsevier merged with the UK publishing giant Reed in 1992 to create yet another Anglo-Dutch conglomerate with sales of fl 9 billion and 25, 800 employees in 1996. This marriage has been followed by a series of divestitures (e.g., the sale of IPC, the UK-based newspapers and magazines division of Reed), and acquisitions (e.g, OAG publications, Lexis-Nexis, MDL information systems). More importantly, in 1997, ReedElsevier acquired Wolters Kluwer, its Dutch rival, itself the 36th largest firm in the Netherlands (Table 1.10) ${ }^{17}$. Prior to its own merger with Reed Elsevier in 1997, Wolters

15. Chemical Week, pp. 26-32, October 271993

16. Chemical Week, pp. 33-34, December 211994

17. At the time of writing (December 1997), this acquisition was being scrutinised by the European commission for possible potential violation of EU competition rules, since the combined firm would have a monopoly position in several fields such as consumer magazine publishing and freight-exchange databases (International Herald Tribune, p.11, December 1314 1997). 
Kluwer had acquired CCH inc., the US tax and legal publisher for US\$1.9 billion in 1995.

This is not to say that Dutch outward FDI activity is mature, and primarily dominated by large MNEs who are engaged in their traditional sectors. Although the Dutch presence in information technologies has been somewhat subdued with the exit of Philips as an OEM manufacturer, it is still heavily involved in the production of components, peripherals, and accessories. Companies such as Tulip have continued to operate profitably in this market, and companies such as Baan have been making some headway in the software sector.

Elsewhere, there are several smaller manufacturing sector firms which have proved highly successful by focussing on niche sectors. Firms such as photocopier manufacturer, Océ -Van der Grinten, which has also been repositioning itself to focus on the engineering market and very high volume copiers, has been successful in competing with its much larger US and Japanese competitors. In 1996, it purchased Siemens' printer-making business. Despite its relatively small size compared to Xerox and Fuji, (with sales of fl 4.1 billion and 17000 employees in 1996, it is less than a tenth the size of Xerox), Océ has the fourth largest R\&D budget amongst Dutch firms, after DSM, Philips, and Shell, and has R\&D establishments in the Netherlands, Germany, France, and the US. It too has been expanding outside its traditional markets, with the acquisition of sales organisations such as Messerli of Switzerland in 1997, and has been strengthening its distribution in other European countries. Europe accounted for $63 \%$ of its sales in 1996 and its presence in the US market has also been growing, with sales in the US increasing from 23\% of its total worldwide sales in 1995 to $31 \%$ in 1996 , with the absolute volume of sales having doubled over that period to fl 1.3 billion.

Another of the great unsung Dutch manufacturing sector success stories has undoubtedly been $\underline{\text { Stork, }}$ which had net sales of almost fl 5 billion in 1996. Its operations are divided into two core areas: Industrial systems and components, and Industrial services. Within these, its operations are divided into several strategic business units: textiles and paper printing, food processing and packaging, industrial components (which absorbed Fokker Aviation after its parent's bankruptcy in $1996^{18}$ ), technical services and engineering and

18. Fokker Aviation is the holding company which controls the profitable divisions of N.V. Koninklijke Vliegtuigenfabriek Fokker, which had previously been acquired by Daimler 
contracting.

\section{Financial MNEs}

The financial sector has perhaps adapted the most, and grown the fastest in terms of internationalisation in response to these changes. They have done so with a determination and drive that may easily be mistaken for a crusade, forging alliances, mergers, and acquisitions at a breathtaking pace. Indeed, Dutch banks were not small by any means, the four largest were 47, 51, 53, and 60 in the Fortune 500 listing of banks in 1989. These same banks are still present in the 1996 Fortune list (Table 1.10), but have evolved much through mergers,

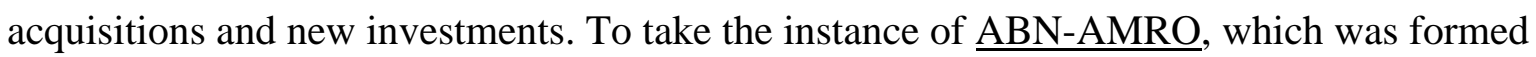
from a merger of the two largest Dutch banks, Algemene Bank Nederland and AmsterdamRotterdam Bank. These two banks had combined assets of US\$ 185 billion in 1989, and by 1995, ABN-AMRO had almost doubled its assets to US\$ 340 billion.

Benz. 
The other large entity is the ING group which became prominent after its highly publicised rescue of Barings in 1995. It was created from the merger of NMB Postbank (number 60 in the Fortune bank rankings of 1989) and Nationale Nederlanden (the largest Dutch insurance company at the time). The collaboration has been very fruitful, since the new bank has had access to investment funds from the cash-rich insurance company to develop international banking operations, and at the same time has been able to expand the international activities in the insurance sector. ING group had assets of US\$ 247 billion in 1995 and revenues of US\$ 33 billion. In 1996, it operated a bank network of over 86 banks in at least 50 countries. ING and ABN-AMRO have tended to directly compete, both having similar expansion plans. Both have an ambition to be a dominant force in emerging markets of Asia and Central and Eastern Europe, and both are listed on the New York Stock Exchange. This is a relatively uncommon event amongst European banks. As of August 1997, no German bank was listed, and amongst British banks, only Barclays ${ }^{19}$.

There are, nonetheless, considerable differences emerging, in part due to their different backgrounds. First, ING has been largely frustrated in its attempts to develop the US market ${ }^{20}$. This is partly because of the Glass-Steagall Act, which limits the ability of banks to sell insurance and vice-versa ${ }^{21}$. ABN-AMRO, on the other hand, does not rely on synergies between the two sectors, and has invested considerable resources (as well as prior to its merger), in developing its US market. Depending on the source of statistics, ABN-AMRO is either the largest (in terms of local assets) or the second largest foreign bank (in terms of revenues) in the US. It has achieved this position through a series of acquisitions since 1979 (see Figure 1.1).

$* * *$ Figure 1.1 about here $* * * * * *$

$\underline{\text { Rabobank, }}$ although less well-known and considerably smaller than the other two Dutch banking MNEs, is also a Fortune 500 company. It has had more modest ambitions ${ }^{22}$,

19. Financial Times, p.39, May 211997.

20. Euromoney, pp. 65-68, November 1996.

21. Financial World, p.87, February 181997.

22. Euromoney, p.68, November 1996. 
planning to be a "global niche player", concentrating on providing service world-wide in its four core specialist areas: food and agriculture, healthcare, financial institutions, and international corporates. It has a very much subdued global ambition, given its origins as a cooperative bank, and subsequently, a more limited access to capital for international expansion. Indeed, it did not have any overseas offices until the early 1980s. Nonetheless, the Rabobank too has begun to make its presence felt. It has done so through joint ventures, while at the same time focussing on these niches. It has a major presence in the Australian agricultural lending market, for instance, having acquired the Primary Industries Bank (PIBA) in $1995^{23}$. It is also active in South and North America in these sectors.

Other Dutch insurance companies have also begun to improve their international presence. Aegon, for instance, has entered the US market, with the acquisition of US insurance company Providian for US\$ 3.5 billion, making it larger than Nationale Nederlanden (one of ING's parents) in terms of assets. Fortis is another insurance firm with banking ambitions, which is listed on both the Belgian and Dutch stock markets (a result of its origins: Fortis is a 1990 merger between Groupe AG of Belgium and Fortis AMEV of the Netherlands). Fortis owns the fifth largest Dutch bank, VSB, which is heavily involved in the Dutch mortgage market, the fourth largest in Europe. Indeed, it is speculated that VSB would like to enter the mortgage markets of more European countries when regulations would allow $\mathrm{it}^{24}$. The purchase of MeesPierson from ABN-Amro in $1996^{25}$ (another product of the merger of the investment banking branches of ABN [Mees \& Hope] and AMRO [Pierson, Heldring and Pierson $]^{26}$ ), demonstrates the objective of expanding their banking operations.

23. Business Review Weekly, p.60, January 221996.

24. Euroweek, (Structured finance Supplement) p.50, June, 1997.

25. Financial Times, p.13, December 311996. 
MeesPierson, whose operations are larger than those of Fortis' existing banking operations, is primarily focussed in investment banking.

\section{Non-financial Service MNEs}

Although the Financial MNEs such as ING and ABN-AMRO have received the most publicity, Dutch MNEs in non-financial services sector have the fastest growing international operations. Excluding the case of KPN (Koninklijke Post en Telecom), the telecommunications utility that privatised in 1989 , there would seem to be four sectors in which Dutch service firms are established: employment services, transportation and distribution services, retail and trading, and environmental services. KPN has sought to prepare itself for the deregulation of the Dutch telecommunications markets by shedding jobs and establishing a series of joint ventures and acquisitions to position itself for subsequent privatisations and deregulations throughout the world. In particular, its small home market base has meant that it has sought to overcome such limitations by allying itself with other similarly-challenged firms. KPN has established, in cooperation with Swedish Telia AB, Swiss Telecom PTT and Telefónica de Espana SA. Unisource has a strategic alliance with AT\&T to establish joint services and standards. Telia and KPN have established a consortium with Ireland's Telecom Ierann, while KPN and Swiss Telecom have jointly acquired a 27\% interest in Czech Republic's SPT Telecom. KPN also has a equity share in PT Telekomsel of Indonesia and is helping establish GSM services throughout the Indonesian peninsula. It also acquired TNT, the Australian courier company for fl 2.25 billion in 1996, adding another 48,000 employees to its payroll.

26. The Banker, p.24, April 1996. 
The retail sector is best exampled by the case of $\underline{\mathrm{Ahold}}$, which like $\underline{\mathrm{SHV}}^{27}$ (which owns Makro), has expanded outside its home market (where it is the market leader, with a market share of 25 percent $^{28}$ since the 1990s). In fact, by 1996 it owned the fifth largest chain of US retail stores. Its sales in this market were US\$ 12.4 billion in 1995. It has expanded primarily through acquisitions - its stated goal is to expand its US presence even further through this means, targeting companies with sales between US\$ 1 and 2 billion over the next few years ${ }^{29}$. Its expansion plans are not just limited to the North American market, with expansions also taking place in Spain, Portugal, Poland, Czech Republic, as well as in South America. It is also developing its Asian presence in Thailand, Malaysia, and China, reportedly opening stores in China at the rate of one per week in the early 1990s.

Not all retail firms have shown such an aggressive approach to internationalisation. Vendex International, one of the largest retailers in the Benelux region with sales of 12 billion in 1996 - its subsidiaries dominate the high street retailers from fashion and groceries to electronics and sports goods - has limited its overseas expansion to Germany and France. Indeed, Vendex's employment services division (Vedior) has been much more aggressive internationally, and is in fact to be separately listed from Vendex's retail operations from $1997^{30}$.

The pioneer in the international employment services sector is Randstad. Randstad is the $24^{\text {th }}$ largest firms in the Netherlands in terms of sales, with over 320 offices in the Netherlands. It is also engaged in several other related service sectors including security,

27. As noted in Table 1.10, SHV is legally domiciled in the Netherlands Antilles.

28. Financial Times, p.30, April 031996.

29. Progressive Grocer, pp. 75-79, January 1994.

30. Financial Times, p.20, January 241997. 
education, and R\&D. More than a third of its net revenues of fl 6 billion in 1996 derived from its international operations, and this share is expected to grow, given its low penetration in other markets, particularly with the growing popularity of 'flexible' work amongst EU countries.

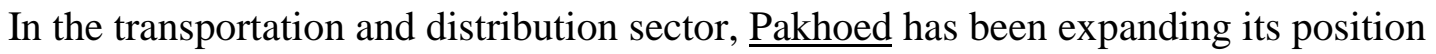
through acquisitions and joint ventures and is now the second largest distribution firm in Europe, and the world leader in chemical distribution, with its 1995 acquisition of Lambert Riviere of France and Univar, the largest North American distributor in that sector. Pakhoed has clear plans to continue its expansion drive, particularly in Asia. Its main Dutch competitor Van Ommeren, also has similar plans, and also intends to improve its position on the shipping side. Nedlloyd, the transportation conglomerate, is also in the process of rationalising, with the sale of its oil and gas drilling subsidiary, Neddrill, to Noble Drilling Corp ${ }^{31}$. In 1996, Nedlloyd agreed to merge its container operations with those of its main European rival, $\mathrm{P} \& \mathrm{O}$ of the UK, to create one of the largest container shipping companies in the world ${ }^{32}$. This is partly in response to low margins and low returns on capital in the container shipping industry, with firms trying to cut costs and raise volumes ${ }^{33}$. It is expected that further mergers are likely.

Companies such as Heidemij (renamed Arcadis in 1997) have developed a dominant position in the engineering services sector, but with a particular focus on environment-related engineering services. Heidemij was originally organised as a public service association, the Vereniging Nederlandsche Heidemaatschappij, as early as 1888, but was restructured and established as a limited company in 1982. Since adopting its current operating structure in 1993, it has sold its non-core businesses in software and computing facilities and real estate agencies. At the same time, it has aggressively expanded its operations, both in the Netherlands as well as in Europe, with $51 \%$ of its sales coming from outside the Netherlands, handling projects in over 80 countries. In addition, it has also undertaken a series of

31. Wall Street Journal, p.B4, 29 April 1996 (eastern edition).

32. Traffic World, p.11, September 161996.

33. Financial Times, p.313, April 1997. 
acquisitions to strengthen its worldwide position (see Figure 1.2). 


\section{REFERENCES}

Belderbos, R.A. (1989) "Buitenlandse investeringen en de internationalisering van de Nederlandse economie (Foreign Direct Investment and the Internationalization of the Dutch Economy)", Tijdschrift voor Politieke Economie, Vol. 12, pp. 14-39.

Cantwell, J. and Bellak, C. (1994) Measuring the Importance of International Production: The

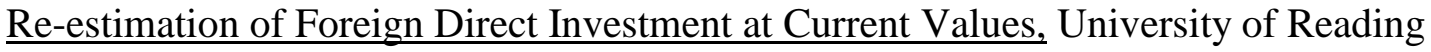
Discussion Papers in International Investment and Business Studies, Series B, Vol VI.

Dunning, J.H. (1993) Globalisation of Business, London: Routledge.

Dunning, J.H. and Narula, R. (1996) The investment development path revisited:some emerging issues, in J. Dunning and R. Narula (eds), Foreign Direct Investment and Governments: Catalysts for Economic Restructuring, London: Routledge, pp. 1-41.

Freeman, C. and Lundvall, B. [eds.] (1988) Small Countries Facing the Technological Revolution, Pinter Publishers: London

Harrold, P. and Lall, R. (1993) China Reform and Development in 1992-93, World Bank Discussion Paper No 215

Narula, R. (1996) Multinational Investment and Economic Structure, Routledge, London

Van Nieuwkerk, M. and R. Sparling (1985) The Netherlands International Direct Investment Position, Dordrecht: Nijhoff.

OECD (1996) country surveys, various issues

UNCTAD (1996) World Investment Report, Geneva: United Nations. 


\section{Table 1.1 Some basic}

\section{indicators}

\begin{tabular}{|c|c|c|c|c|c|c|c|c|c|c|}
\hline & $\begin{array}{r}\text { Netherlan } \\
\text { ds }\end{array}$ & Belgium & \multicolumn{2}{|c|}{ France German } & Italy & \multicolumn{2}{|c|}{$\begin{array}{r}\text { UK Switzerlan } \\
d\end{array}$} & Canada & US & Japan \\
\hline$\overline{\text { Population }}$ & 15457 & 10137 & 58141 & 81662 & 57283 & 58613 & 7081 & 29606 & 263057 & 125250 \\
\hline $\begin{array}{l}\text { GDP (bln.US\$; } \\
\text { PPPs) }\end{array}$ & 305.6 & 210.8 & 1159.3 & 1673.8 & 1114.7 & 1041.9 & 175.7 & 622.6 & 6954.8 & 2736.8 \\
\hline $\begin{array}{l}\text { GDP per capita } \\
\text { (PPPs) } \\
\text { Sectoral GDP }\end{array}$ & 19782 & 21031 & 19939 & 20497 & 19465 & 17776 & 24809 & 21031 & 26438 & 21795 \\
\hline Primary & 4.0 & 1.9 & 0.5 & 1.3 & 3.4 & 2.2 & 3.4 & 3.0 & 1.9 & 2.3 \\
\hline Secondary & 31.8 & 23.8 & 33.6 & 41.1 & 37 & 34.4 & 37.4 & 36.5 & 28.8 & 40.6 \\
\hline Tertiary & 64.1 & 74.2 & 65.8 & 57.7 & 59.6 & 63.4 & 59.3 & 60.6 & 69.3 & 57.1 \\
\hline Sectoral labour & & & & & & & & & & \\
\hline Agriculture & 4.0 & 2.6 & 5.1 & 3.3 & 7.7 & 2.1 & 4.0 & 4.1 & 2.9 & 5.8 \\
\hline Indus & 23.0 & 27.7 & 27.8 & 37.6 & 32.1 & 27.7 & 28.8 & 22.6 & 24.0 & 34.0 \\
\hline Services & 73.0 & 69.7 & 67.3 & 59.1 & 60.2 & 70.2 & 67.3 & 73.3 & 73.1 & 60.2 \\
\hline Export (fob) & 197087 & 170230 & 286762 & 523000 & 233868 & 242692 & 81499 & 192502 & 584742 & 441512 \\
\hline Export/GDP & 49.8 & 63.2 & 18.7 & 21.7 & 21.5 & 22.0 & 26.6 & 34.4 & 8.4 & 8.6 \\
\hline Import (cif) & 177912 & 155449 & 267059 & 463472 & 206246 & 265696 & 80193 & 164443 & 743445 & 335392 \\
\hline Import/GDP & 45.0 & 29.4 & 17.4 & 19.2 & 19.0 & 24.1 & 26.2 & 29.4 & 10.7 & 6.6 \\
\hline
\end{tabular}

Source: OECD Economic Surveys, various issues 
Table 1.2 Productivity in business sectors

\begin{tabular}{|c|c|c|c|c|c|}
\hline & & Netherlands & N.W. Europe ${ }^{a}$ & EU & $\overline{\text { OECD }}$ \\
\hline & & \multicolumn{4}{|c|}{ (Annual compound growth rates) } \\
\hline \multirow[t]{4}{*}{ Real GDP per capita } & $1960-73$ & 3.57 & 3.63 & 4.25 & 3.94 \\
\hline & 1973-87 & 1.21 & 1.83 & 1.81 & 1.84 \\
\hline & $1987-94$ & 1.83 & 1.13 & 1.52 & 1.32 \\
\hline & $1960-94$ & 2.24 & 2.37 & 2.67 & 2.53 \\
\hline \multirow[t]{5}{*}{ GDP per hour worked } & $1960-73$ & 5.25 & 4.89 & 5.59 & 4.84 \\
\hline & 1973-87 & 2.60 & 2.41 & 2.51 & 2.31 \\
\hline & 1987-94 & 1.49 & 2.05 & 2.31 & 2.13 \\
\hline & $1960-94$ & 3.37 & 3.25 & 3.64 & 3.23 \\
\hline & \multicolumn{5}{|c|}{ (as \% of the Netherlands) } \\
\hline \multirow[t]{4}{*}{ GDP per capita } & $1960-73$ & 100 & 100 & 79 & 86 \\
\hline & 1973-87 & 100 & 100 & 86 & 90 \\
\hline & $1987-94$ & 100 & 109 & 93 & 98 \\
\hline & $1960-94$ & 100 & 104 & 91 & 94 \\
\hline \multirow[t]{4}{*}{ GDP per hour worked } & $1960-73$ & 100 & 91 & 74 & 86 \\
\hline & 1973-87 & 100 & 87 & 77 & 82 \\
\hline & 1987-94 & 100 & 85 & 77 & 79 \\
\hline & $1960-94$ & 100 & 88 & 81 & 82 \\
\hline
\end{tabular}

Source: OECD Economic Surveys 1995-1996, the Netherlands

a. Austria, Belgium, Denmark, France, Germany, the Netherlands, Norway, Sweden, Switzerland and the United Kingdom. 
Table 1.3 Geographical destination of Dutch exports

\begin{tabular}{lrrrrr}
\hline & 1975 & 1980 & 1985 & 1990 & 1994 \\
\hline EU & 71.3 & 72.2 & 74.0 & 72.0 & 70.7 \\
EFTA & 6.4 & 6.9 & 5.8 & 5.7 & 2.3 \\
USA & 2.8 & 2.5 & 5.2 & 3.6 & 3.7 \\
Africa & 4.0 & 4.0 & 3.0 & 2.0 & 1.6 \\
Asia & 5.9 & 6.6 & 6.2 & 5.0 & 6.0 \\
Other & 9.6 & 7.8 & 5.8 & 11.7 & 15.7 \\
countries & & & & & \\
\hline & 100 & 100 & 100 & 100 & 100 \\
\hline
\end{tabular}

Source: UN International Trade Statistics 
Table 1.4 Product composition of Dutch exports (share

of product group)

\begin{tabular}{lrrrrr}
\hline & 1975 & 1980 & 1985 & 1990 & 1994 \\
\hline 1 Agriculture & 9.5 & 7.7 & 7.2 & 8.3 & 8.5 \\
2 Mining quarry & 6.1 & 8.8 & 9.0 & 3.4 & 3.0 \\
3 Manufacturing & 84.4 & 83.5 & 83.3 & 88.3 & 88.5 \\
31 Food beverages and & 15.8 & 14.9 & 15.3 & 15.6 & 16.4 \\
tobacco & & & & & \\
32 Textiles & 6.1 & 4.7 & 4.3 & 4.4 & 4.2 \\
33 Wood \& products & 0.3 & 0.4 & 0.3 & 0.5 & 0.6 \\
34 Paper \& products & 2.2 & 2.2 & 2.3 & 3.1 & 2.9 \\
35 Chemicals & 28.1 & 30.9 & 33.4 & 24.5 & 22.7 \\
36 Nonmetal products & 1.0 & 0.9 & 0.8 & 1.1 & 1.0 \\
37 Basic metals & 5.3 & 5.5 & 4.2 & 4.2 & 3.8 \\
38 Metal manufacturing & 24.8 & 22.3 & 22.0 & 30.2 & 31.8 \\
39 Other manufacturing & 0.9 & 1.8 & 0.5 & 4.7 & 5.1 \\
\hline & 100.1 & 100.1 & 99.3 & 100 & 100 \\
\hline
\end{tabular}

Source: UN International Trade Statistics 


\begin{tabular}{|c|c|c|c|c|c|}
\hline & 1975 & 1980 & 1985 & 1990 & 1994 \\
\hline \multicolumn{6}{|l|}{ Netherlands } \\
\hline FDI stock (US\$ mln.) & 19922 & 42116 & 47772 & 109124 & 146035 \\
\hline Share global FDI stock & $7.10 \%$ & $8.20 \%$ & $7.00 \%$ & $6.50 \%$ & $6.10 \%$ \\
\hline FDI stock per capita (US\$1,000) & 1.46 & 2.98 & 3.30 & 7.30 & 9.49 \\
\hline FDIstock/GDP & 0.245 & 0.245 & 0.382 & 0.391 & 0.437 \\
\hline FDlstock/EXP & 0.570 & 0.570 & 0.700 & 0.828 & 0.942 \\
\hline \multicolumn{6}{|l|}{ France } \\
\hline FDI stock (US\$ mln.) & 10608 & 23604 & 37077 & 110126 & 183406 \\
\hline Share global FDI stock & $3.80 \%$ & $4.60 \%$ & $5.50 \%$ & $6.60 \%$ & $7.70 \%$ \\
\hline FDI stock per capita (US\$1,000) & 0.20 & 0.44 & 0.67 & 1.95 & 3.16 \\
\hline FDIstock/GDP & 0.032 & 0.036 & 0.073 & 0.092 & 0.138 \\
\hline FDIstockEXP & 0.206 & 0.213 & 0.381 & 0.509 & 0.779 \\
\hline \multicolumn{6}{|l|}{ Germany } \\
\hline FDI stock (US\$ mln.) & 14354 & 43127 & 59909 & 151581 & 205608 \\
\hline Share global FDI stock & $5.10 \%$ & $8.40 \%$ & $8.80 \%$ & $9.10 \%$ & $8.60 \%$ \\
\hline FDI stock per capita (US\$1,000) & 0.23 & 0.70 & 0.98 & 2.40 & 2.53 \\
\hline FDIstock/GDP & 0.034 & 0.053 & 0.096 & 0.102 & 0.112 \\
\hline FDlstock/EXP & 0.159 & 0.225 & 0.327 & 0.370 & 0.487 \\
\hline \multicolumn{6}{|l|}{ Italy } \\
\hline FDI stock (US\$ mln.) & 3299 & 7319 & 16301 & 56102 & 83462 \\
\hline Share global FDI stock & $1.20 \%$ & $1.40 \%$ & $2.40 \%$ & $3.40 \%$ & $3.50 \%$ \\
\hline FDI stock per capita (US\$1,000) & 0.06 & 0.13 & 0.29 & 0.97 & 1.46 \\
\hline FDIstock/GDP & 0.019 & 0.016 & 0.045 & 0.051 & 0.082 \\
\hline FDIstock/EXP & 0.095 & 0.094 & 0.206 & 0.329 & 0.440 \\
\hline \multicolumn{6}{|l|}{ UK } \\
\hline FDI stock (US\$ mln.) & 37002 & 80434 & 100313 & 230825 & 281170 \\
\hline Share global FDI stock & $13.20 \%$ & $15.60 \%$ & $14.80 \%$ & $13.80 \%$ & $11.80 \%$ \\
\hline FDI stock per capita (US\$1,000) & 0.66 & 1.43 & 1.77 & 4.02 & 4.82 \\
\hline FDIstock/GDP & 0.162 & 0.150 & 0.223 & 0.241 & 0.276 \\
\hline FDIstock/EXP & 0.846 & 0.703 & 0.991 & 1.243 & 1.370 \\
\hline \multicolumn{6}{|l|}{ Switzerland } \\
\hline FDI stock (US\$ mln.) & 22443 & 21491 & 21350 & 65731 & 95328 \\
\hline Share global FDI stock & $8.00 \%$ & $4.20 \%$ & $3.10 \%$ & $3.90 \%$ & $4.00 \%$ \\
\hline FDI stock per capita (US\$1,000) & 3.50 & 3.40 & 3.30 & 9.67 & 13.63 \\
\hline
\end{tabular}




\begin{tabular}{|c|c|c|c|c|c|}
\hline FDIstock/GDP & 0.414 & 0.211 & 0.230 & 0.292 & 0.370 \\
\hline FDlstock/EXP & 1.733 & 0.729 & 0.783 & 1.030 & 1.353 \\
\hline \multicolumn{6}{|l|}{ Canada } \\
\hline FDI stock (US\$ mln.) & 10356 & 22572 & 40947 & 78853 & 105606 \\
\hline Share global FDls & $3.70 \%$ & $4.40 \%$ & $6.00 \%$ & $4.70 \%$ & $4.40 \%$ \\
\hline FDI stock per capita (US $\$ 1,000)$ & 0.46 & 0.94 & 1.63 & 2.96 & 3.61 \\
\hline FDlstock/GDP & 0.065 & 0.086 & 0.118 & 0.138 & 0.194 \\
\hline FDlstock/EXP & 0.321 & 0.358 & 0.476 & 0.619 & 0.639 \\
\hline \multicolumn{6}{|l|}{ US } \\
\hline FDI stock (US\$ mln.) & 124050 & 220178 & 251034 & 435219 & 610061 \\
\hline Share global FDI stock & $44.30 \%$ & $42.80 \%$ & $36.90 \%$ & $26.10 \%$ & $25.70 \%$ \\
\hline FDI stock per capita (US $\$ 1,000)$ & 0.58 & 0.97 & 1.05 & 1.73 & 2.34 \\
\hline FDlstock/GDP & 0.082 & 0.081 & 0.064 & 0.081 & 0.092 \\
\hline FDIstock/EXP & 1.169 & 1.034 & 1.223 & 1.105 & 1.190 \\
\hline \multicolumn{6}{|l|}{ Japan } \\
\hline FDI stock (US\$ mln.) & 15941 & 19610 & 43970 & 201440 & 277733 \\
\hline Share global FDI stock & $5.70 \%$ & $3.80 \%$ & $6.50 \%$ & $12.10 \%$ & $11.70 \%$ \\
\hline FDI stock per capita (US\$1,000) & 0.14 & 0.17 & 0.36 & 1.63 & 2.22 \\
\hline FDlstock/GDP & 0.032 & 0.019 & 0.033 & 0.069 & 0.061 \\
\hline FDlstock/EXP & 0.286 & 0.151 & 0.250 & 0.701 & 0.701 \\
\hline Global FDI stock & 280136 & 514224 & 679393 & 1667579 & 2378025 \\
\hline
\end{tabular}


Table 1.6 Geographical division of Dutch FDI stock in the world (Millions of guilders and share in total)

\begin{tabular}{|c|c|c|c|c|c|c|c|c|c|c|c|c|}
\hline & 1973 & $\%$ & 1975 & $\%$ & 1980 & $\%$ & 1985 & $\%$ & 1990 & $\%$ & 1995 & $\%$ \\
\hline EU & 22335 & 50.6 & 28006 & 52.3 & 42965 & 47.9 & 43493 & 32.8 & 83719 & 45.7 & 139078 & 49.2 \\
\hline Austria & & & & & & & & & & & 2363 & 0.8 \\
\hline Belgium-Luxembourg & 3132 & 7.1 & 4139 & 7.7 & 6345 & 7.1 & 10060 & 7.6 & 21382 & 11.7 & 37675 & 13.3 \\
\hline Denmark & 345 & 0.8 & 551 & 1.0 & 813 & 0.9 & 626 & 0.5 & 1348 & 0.7 & 3206 & 1.1 \\
\hline Germany & 8324 & 18.8 & 8807 & 16.4 & 9806 & 10.9 & 12422 & 9.4 & 17479 & 9.5 & 22115 & 7.8 \\
\hline Finland & & & & & & & & & & 0.0 & 510 & 0.2 \\
\hline France & 2815 & 6.4 & 3570 & 6.7 & 6169 & 6.9 & 7188 & 5.4 & 14188 & 7.7 & 18568 & 6.6 \\
\hline Ireland & 120 & 0.3 & 120 & 0.2 & 508 & 0.6 & 805 & 0.6 & 1046 & 0.6 & 5047 & 1.8 \\
\hline Italy & 803 & 1.8 & 720 & 1.3 & 1322 & 1.5 & 1797 & 1.4 & 2705 & 1.5 & 3861 & 1.4 \\
\hline Spain & & & & & & & 2513 & 1.9 & 5632 & 3.1 & 9044 & 3.2 \\
\hline Sweden & & & & & & & & & & & 3337 & 1.2 \\
\hline United Kingdom & 6796 & 15.4 & 10099 & 18.9 & 18002 & 20.1 & 7620 & 5.7 & 18846 & 10.3 & 31182 & 11.0 \\
\hline Other EU & & & & & & & 462 & 0.3 & 1093 & 0.6 & 2170 & 0.8 \\
\hline Other Europe & & & & & & & 9704 & 7.3 & 15885 & 8.7 & 23907 & 8.5 \\
\hline Switzerland & 1025 & 2.3 & 1568 & 2.9 & 4216 & 4.7 & 7619 & 5.7 & 12847 & 7.0 & 18964 & 6.7 \\
\hline Central and Eastern Europe & & & & & & & 5 & 0.0 & 23 & 0.0 & 2729 & 1.0 \\
\hline USA & 6200 & 14.0 & 7126 & 13.3 & 16864 & 18.8 & 54343 & 41.0 & 53666 & 29.3 & 69759 & 24.7 \\
\hline Latin America and the Caribbean & 5278 & 11.9 & 6079 & 11.3 & 10145 & 11.3 & 10180 & 7.7 & 12020 & 6.6 & 18232 & 6.5 \\
\hline Netherlands Antilles (1) & 2575 & 5.8 & 3804 & 7.1 & 6399 & 7.1 & 6557 & 4.9 & 7547 & 4.1 & 8420 & 3.0 \\
\hline Africa & 201 & 0.5 & 601 & 1.1 & 843 & 0.9 & 2249 & 1.7 & 1839 & 1.0 & 3244 & 1.1 \\
\hline Japan & & & & & & & 1270 & 1.0 & 1677 & 0.9 & 2351 & 0.8 \\
\hline Other countries & 9134 & 20.7 & 10181 & 19.0 & 14652 & 16.3 & 11292 & 8.5 & 14316 & 7.8 & 26058 & 9.2 \\
\hline Southeast Asia (2) & 1738 & 3.9 & 1923 & 3.6 & 3991 & 4.5 & 3971 & 3.0 & 5439 & 3.0 & 13971 & 4.9 \\
\hline TOTAL & 44173 & 100.0 & 53561 & 100.0 & 89685 & 100.0 & 132531 & 100.0 & 183122 & 100.0 & 282630 & 100.0 \\
\hline
\end{tabular}

Source: De Nederlandsche Bank

1) Including Aruba

2) Including all developing countries within Asia 
Table 1.7 Sectoral division of Dutch outward FDI Stock (Millions of guilders and share of total)

\begin{tabular}{|c|c|c|c|c|c|c|c|c|c|c|c|c|}
\hline & 1973 & $\%$ & 1975 & $\%$ & 1980 & $\%$ & 1985 & $\%$ & 1990 & $\%$ & 1995 & $\%$ \\
\hline PRIMARY & 127 & 0.3 & 137 & 0.3 & 439 & 0.5 & 125 & 0.1 & 193 & 0.1 & 176 & $\overline{0.1}$ \\
\hline Agriculture & 127 & 0.3 & 137 & 0.3 & 439 & 0.5 & 125 & 0.1 & 193 & 0.1 & 176 & 0.1 \\
\hline Mining and quarrying & & & & & & & .. & & .. & & .. & \\
\hline Oil & & & & & & & .. & & .. & & .. & \\
\hline SECONDARY & 38215 & 86.5 & 45577 & 85.1 & 72203 & 80.5 & 87925 & 66.3 & 103948 & 56.8 & 143938 & 50.9 \\
\hline Food, beverages and tobacco & 5863 & 13.3 & 6063 & 11.3 & 7103 & 7.9 & 11128 & 8.4 & 16326 & 8.9 & 27127 & 9.6 \\
\hline Textiles, leather and clothing & & & & & & & .. & & .. & & .. & \\
\hline Paper, printing and publishing & & & & & & & .. & & .. & & .. & \\
\hline Chemical products (1) & 20914 & 47.3 & 24918 & 46.5 & 45794 & 51.1 & 56486 & 42.6 & 59753 & 32.6 & 74796 & 26.5 \\
\hline Coal and petroleum products & & & & & & & .. & & .. & & .. & \\
\hline Non-metallic products & & & & & & & .. & & .. & & .. & \\
\hline Metal products (2) & 10634 & 24.1 & 13544 & 25.3 & 17394 & 19.4 & 18447 & 13.9 & 21855 & 11.9 & 28444 & 10.1 \\
\hline $\begin{array}{l}\text { Mechanical equipment } \\
\text { Electric and electronic equipment } \\
\text { Motor vehicles } \\
\text { Other transport equipment }\end{array}$ & & & & & & & $\begin{array}{l}. . \\
. . \\
. .\end{array}$ & & $\begin{array}{l}. . \\
. . \\
. .\end{array}$ & & $\begin{array}{l}. . \\
. . \\
. .\end{array}$ & \\
\hline Other manufacturing & 804 & 1.8 & 1052 & 2.0 & 1912 & 2.1 & 1864 & 1.4 & 6014 & 3.3 & 13571 & 4.8 \\
\hline TERTIARY & 5831 & 13.2 & 7847 & 14.7 & 17043 & 19.0 & 44481 & 33.6 & 78981 & 43.1 & 138515 & 49.0 \\
\hline Construction & 495 & 1.1 & 837 & 1.6 & 1189 & 1.3 & 1068 & 0.8 & 594 & 0.3 & 1986 & 0.7 \\
\hline Wholesale and retail trade & 2365 & 5.4 & 2890 & 5.4 & 6549 & 7.3 & 5489 & 4.1 & 12786 & 7.0 & 29587 & 10.5 \\
\hline Transport and storage (3) & 1312 & 3.0 & 1658 & 3.1 & 1491 & 1.7 & 1591 & 1.2 & 2701 & 1.5 & 4743 & 1.7 \\
\hline Finance, insurance and business serv. (4) & 1659 & 3.8 & 2462 & 4.6 & 7814 & 8.7 & 36333 & 27.4 & 62900 & 34.3 & 102199 & 36.2 \\
\hline Communication & & & & & & & .. & & .. & & .. & \\
\hline Other services (5) & & & & & & & .. & & .. & & .. & \\
\hline UNALLOCATED & & & & & & & .. & & .. & & .. & \\
\hline TOTAL & 44173 & 100.0 & 53561 & 100.0 & 89685 & 100.0 & 132531 & 100.0 & 183122 & 100.0 & 282629 & 100.0 \\
\hline
\end{tabular}

1. Up to 1992, including mining and quarrying, oil and chemicals.

2. Up to 1992 , including metal and electrical engineering.

3. Up to 1992 , including transport, storage and communication.

4. Up to 1992, including other services. As from 1993, including real estate activities.

5. Including electricity, gas, water, hotels, restaurants and other services. 
Table 1.8 Dutch Outward FDI stock by country and sector, 1995 (millions of guilders)

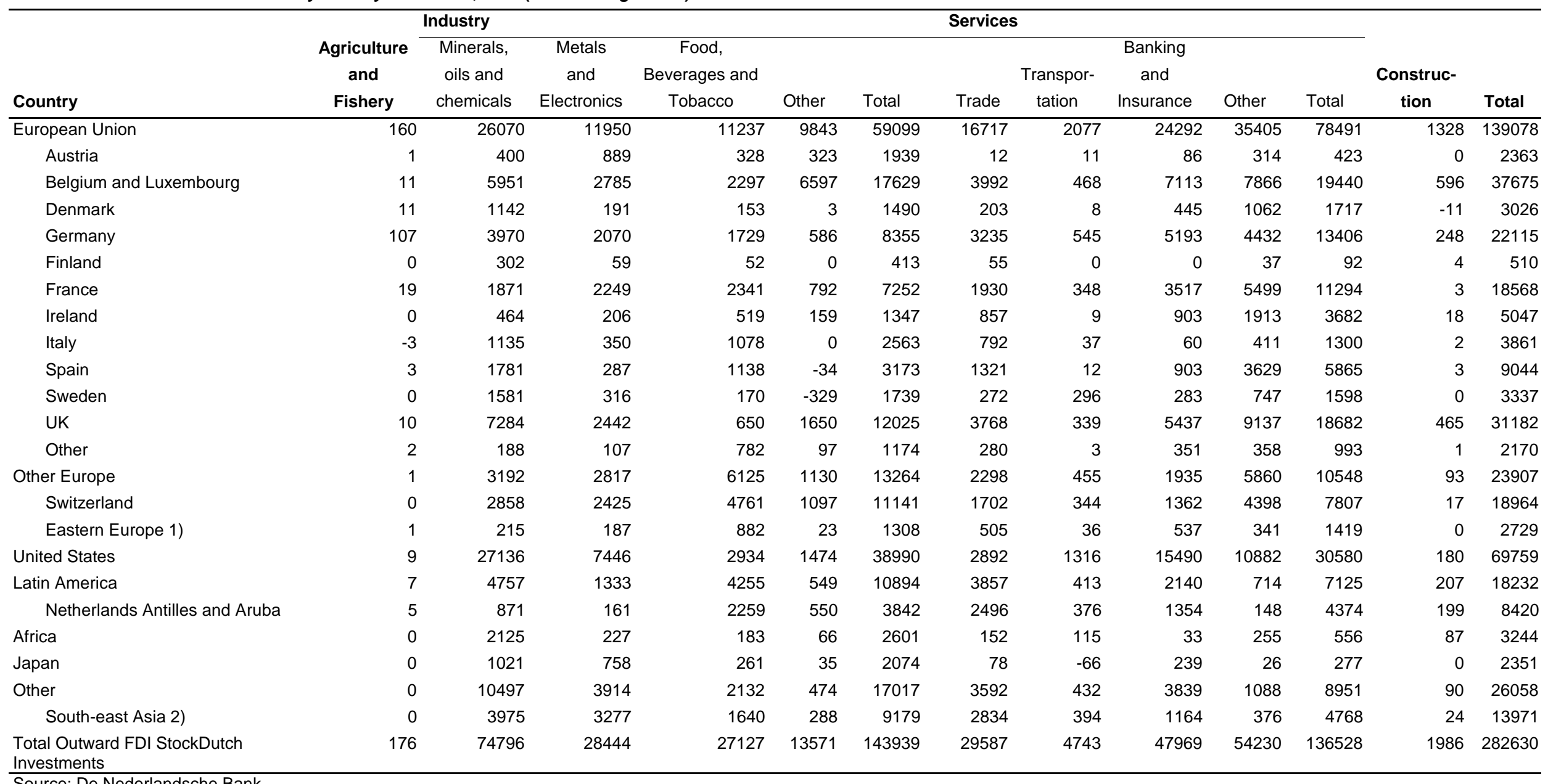

Source: De Nederlandsche Bank

1) Eastern Europe consists of Albania, Czeck Republic, Bulgaria, Hungary, Poland, Rumania, Slovakia, the Soviet Union and former Yugoslavia 
2) South East Asia consists of China, Hong Kong, Indonesia, Malaysia, the Philippines, Singapore, South Korea, Taiwan and Thailand 
Table 1.9 Profile of large MNEs from some small industrialised

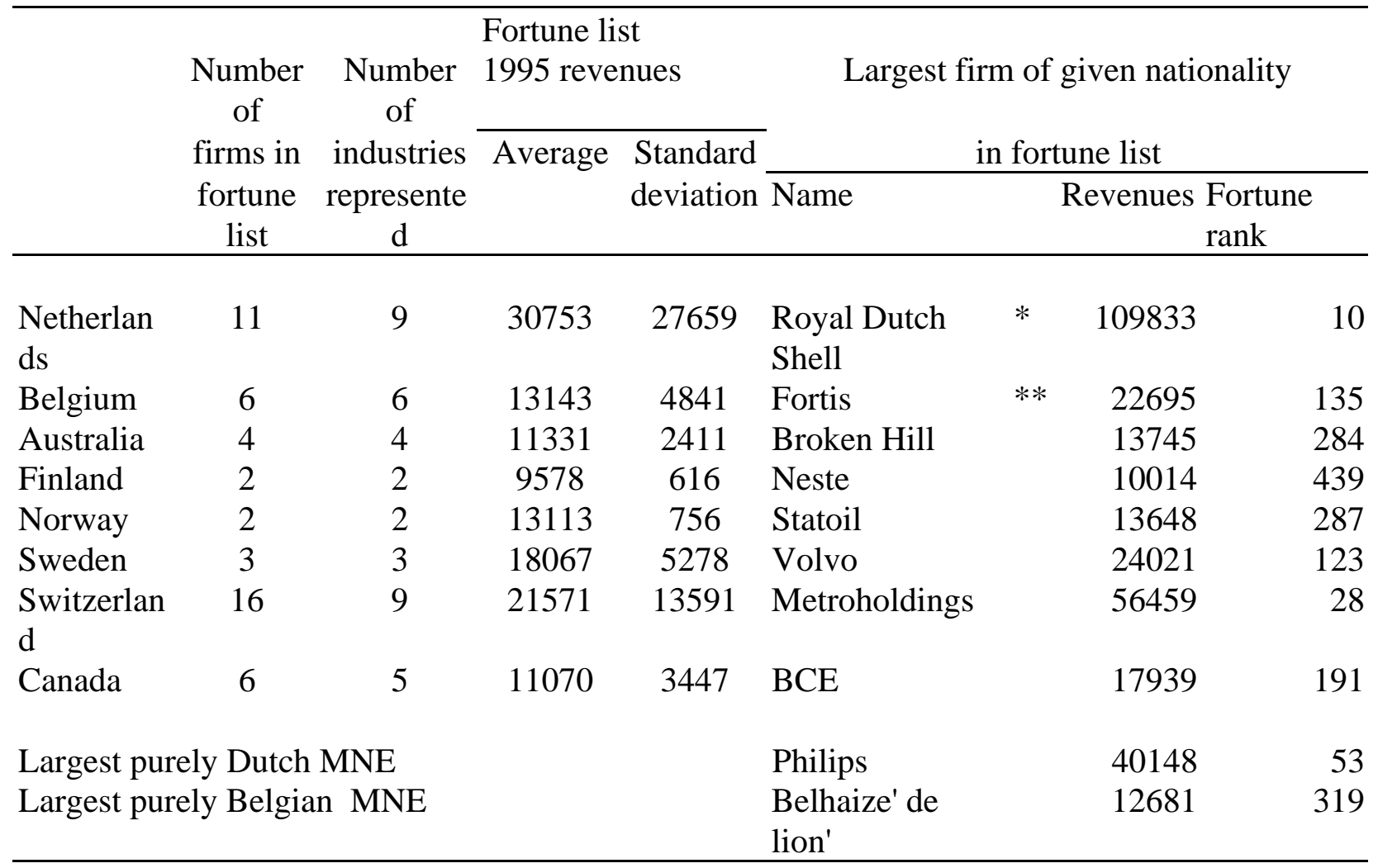

* Dutch/British ownership

**Belgian/Dutch ownership 
TABLE 1.10 Some of the most significant Dutch MNEs, by industrial sector.

\begin{tabular}{|c|c|c|c|c|c|}
\hline Name & Industry & $\begin{array}{c}\text { Dutch } \\
\text { Ranking }{ }^{5} \text { by } \\
1995 \text { revenues }\end{array}$ & $\begin{array}{c}1996 \\
\text { Revenues } \\
\text { (mln guilders) }\end{array}$ & \multicolumn{2}{|c|}{ Rank in Fortune list } \\
\hline \multicolumn{6}{|l|}{ Manufacturing MNEs } \\
\hline Royal Dutch Shell ${ }^{2}$ & Petroleum \& refining & 1 & 215753 & 10 & 4 \\
\hline Unilever $^{2}$ & Food and personal products & 2 & 87795 & 38 & 18 \\
\hline Philips & Electronics \& electrical equipment & 3 & 69195 & 53 & 29 \\
\hline Akzo Nobel $^{3}$ & Chemicals & 8 & 22438 & 300 & 142 \\
\hline KNP BT & Paper and packaging & 12 & 13637 & & \\
\hline Heineken & Beverages & 15 & 12189 & & 403 \\
\hline DSM & Chemicals & 16 & 10263 & & 266 \\
\hline Reed-Elsevier ${ }^{2,4}$ & Printing and publishing & 19 & 8901 & & 460 \\
\hline Polygram & Music and entertaiment & 20 & 9488 & & \\
\hline Hoogovens & Steel & 21 & 7933 & & 307 \\
\hline Stork & Machinery and eng. services & 30 & 4916 & & \\
\hline Wolters Kluwer & Printing and publishing & 28 & 4315 & & \\
\hline Van Leer & packaging & 32 & 4179 & & \\
\hline Oce-van der Grinten & Photocopiers and printers & 39 & 4174 & & \\
\hline CSM & Food products & 40 & 3026 & & \\
\hline Gist Brocades & Biotechnology/ food additives & 47 & 2020 & & \\
\hline Tulip & Computers & 94 & $532=$ & k & \\
\hline Baan & Software & 109 & 348 & 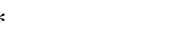 & \\
\hline \multicolumn{6}{|c|}{ Non-financial service MNEs } \\
\hline Ahold & Retail & 6 & 36538 & 185 & \\
\hline SHV & Retail & 7 & 29963 & 230 & \\
\hline KPN & Telecommunications & 10 & 20505 & 345 & \\
\hline Vendex International & Retail & 14 & 12145 & & \\
\hline KLM & Air transport & 17 & 10358 & & \\
\hline Nedlloyd & Sea transport & 22 & 6831 & & \\
\hline Pakhoed & Storage/transportation & 45 & 3594 & & \\
\hline Randstad & Employment & 26 & 5953 & & \\
\hline Heidemij (Arcadis) & Environmental engineering & 71 & 1066 & & \\
\hline Van Ommeron & Storage/transportation & 72 & 880 & k & \\
\hline \multicolumn{6}{|l|}{ Financial MNEs } \\
\hline ING & Insurance/banking & 4 & 47551 & 72 & \\
\hline FORTIS $^{1}$ & Insurance/banking & 5 & 40774 & 135 & \\
\hline AEGON & Insurance/banking & 9 & 24487 & 307 & \\
\hline ABN-AMRO & Banking & 11 & 19091 & 105 & \\
\hline RABOBANK & Banking & 18 & 9647 & 297 & \\
\hline
\end{tabular}

Sources: Revenues based on estimates from Het Financieel Dagblad: de omzetcijfers van 1996;

Jaarboek van Nederlandse ondernemingen 1995/96, Uitgeverij Tutein Nolthenius, 9th edition, and annual reports.

Fortune rankings from Fortune August 5, 1995, and July 30, 1990.

\# Dutch rankings based on Jaarboek van Nederlandse ondernemingen 1995/96, Uitgeverij Tutein Nolthenius, 9th edition. Adjusted for SHV (legally domiciled in the Netherlands Antilles, position 7) and Rabobank (not listed on the stock exchange, at position 18). This has moved all other companies down one or two positions.

1) Fortis is of joint Belgian and Netherlands nationality. 1996 revenues exclude MeesPierson.

2) Reed-Elsevier, Shell and Unilever are of joint British and Dutch ownership.

3) 1989 Fortune ranking for Akzo Nobel for Akzo only.

4) 1989 Fortune ranking for Reed -Elsevier for Reed only.

5) Dutch ranking list includes foreign-owned affiliates in the Netherlands.

* 1995 figures 
